\title{
Alport Sendromu tanısında böbrek biyopsisi ve elektron mikroskobinin önemi
}

\author{
Serra Sürmeli Döven1, Selçuk Teke², İclal Gürses³, Banu Coşkun Yılmaz4, \\ Ebru Ballı ${ }^{4}$ Ali Delibaș ${ }^{1}$ \\ ${ }_{1}^{1}$ Mersin Üniversitesi Tıp Fakültesi Çocuk Nefroloji Bilim Dalı, Mersin \\ 2Mersin Üniversitesi Tıp Fakültesi Çocuk Sağlığı ve Hastalıkları Anabilim Dalı, Mersin \\ ${ }_{3}^{3}$ Mersin Üniversitesi Tıp Fakültesi Patoloji Anabilim Dalı, Mersin \\ ${ }^{4}$ Mersin Üniversitesi Tıp Fakültesi Histoloji ve Embriyoloji Anabilim Dalı, Mersin
}

Öz

Amaç: Alport sendromu hematüri, ilerleyici böbrek yetmezliği, işitme kaybı ve oküler anormalliklerle seyreden bir hastalıktır. Bu çalışmada merkezimizde Alport sendromu tanısıyla izlenen hastaların demografik, klinik ve laboratuvar bulguları ile renal biyopsilerinin histopatolojik ve elektron mikroskobik bulgularının değerlendirilmesi amaçlanmıştır. Yöntem: Çocuk Nefroloji Kliniğinde Haziran 2004 ile Ocak 2018 tarihleri arasında takip edilen 14 Alport sendromlu hastanın başvuru şikayetleri, aile hikayesi, renal tutulumu, göz ve işitme bulguları, böbrek biyopsilerinin histopatolojik ve elektron mikroskobik değerlendirmeleri geriye dönük olarak incelendi. Bulgular: Yedisi kız ve yedisi erkek olmak üzere toplam 14 hasta değerlendirildi. Hastaların yaşları 15 ay-17 yıl arasındaydı (ortalama 10.7 \pm 3.8 yıl). On bir hasta hematüri, bir hasta vücutta şişlik, iki hasta ise şikâyeti olmaksızın ailelerinde Alport sendromu öyküsü olması nedeniyle araştırılmak üzere başvurdu. Anne-baba arasında akrabalık beş hastada bulunurken, 11 hastanın ailesinde Alport sendromu öyküsü mevcuttu. Sensorinöral işitme kaybı yedi hastada saptandı. Bilateral anterior lentikonus son dönem böbrek yetmezliği kliniğinde başvuran bir hastada saptandı. Böbrek biyopsisi yapılan 10 hastanın elektron mikroskobik incelenmesinde, tüm vakalarda glomerül bazal membranında incelmeler, kalınlaşmalar ve sepet görünümü ile karakterize düzensizlikler gösterildi. Sonuç: Hematüri şikayetiyle başvuran hastalarda aile öyküsünün sorgulanması, göz muayenesi ve işitme testlerinin yapılması Alport sendromu tanısını koymada yol gösterici olmaktadır. Elektron mikroskobide glomerul bazal membrandaki tipik değişikliklerin görülmesi tanıyı kesinleștirmektedir.

Anahtar kelimeler: Alport sendromu, anterior lentikonus, elektron mikroskobi, hematüri, işitme kaybı

Yazının başvuru tarihi: 12.02 .2018

Yazının kabul tarihi: 06.03.2018

Sorumlu Yazar: Serra Sürmeli Döven, Mersin Üniversitesi Tıp Fakültesi Çocuk Nefroloji Bilim Dalı, Çiftlikköy-Yenişehir/Mersin Tel: 0324 2410000-22043, E-posta: serrasurmel@yahoo.com

Not: Bu çalışma 24-27.Kasım.2016 Tarihinde Antalya'da Milli Pediatri Kongresi'nde poster olarak sunulmuştur. 


\title{
Kidney biopsy in Alport Syndrome and the importance of electron microscopy
}

\begin{abstract}
Aim: Alport syndrome is characterized by hematuria, progressive renal failure, hearing loss, and ocular abnormalities. This study aims to evaluate demographic, clinic and laboratory findings, and histopathologic and electron microscopic features of renal biopsies of the patients with Alport syndrome who were followed-up in our institution. Methods: Fourteen patients with Alport syndrome who were followed-up from June 2004 to January 2018 were included in this study. The complaints on admission, family history for Alport syndrome, renal involvement, eye and hearing findings and renal biopsy findings were reviewed retrospectively in these patients. Results: Seven girls and seven males were evaluated. The ages of the patiens were between 15 months-17 years (mean: $10.7 \pm 3.8$ years). Eleven patients had hematuria, one patient had edema. Two patients who had no complaints were admitted to be evaluated for the family history of Alport syndrome. Parental consanguinity and family history were peresent in five and 11 patients, respectively. Sensorineural hearing loss was detected in seven patients. Bilateral lenticonus was present in one patient with end stage renal disease. In all of the ten patients who were performed renal biopsy, the thickening and thinning of the glomerul capillary wall with a " basket-weave" appearance was detected by electron microscopy. Conclusion: Family history, eye examination and hearing tests in patients with hematuria leads to the diagnosis of Alport syndrome. The electron microscopy confirms the diagnosis by detecting typical changes in glomerular basement membrane.
\end{abstract}

Key words: Alport syndrome, anterior lenticonus, electron microscopy, hematuria, hearing loss

\section{Giriş}

Alport sendromu (AS) siklıkla sensorinöral işitme kaybı ve göz tutulumu ile birlikte seyreden, ilerleyici, kalıtsal bir nefrittir. ${ }^{1}$ Ilk olarak 1927 de Cecil A. Alport tarafından tanımlanmıştır. ${ }^{2}$ Amerika Birleşik Devletleri'nde canlı doğumların 1/500010000 'inde görülür. ${ }^{3}$ Çocukluk çağında son dönem böbrek yetmezliği gelişen vakaların \%3'ünü oluşturur. ${ }^{4}$ Türkiye'de yapılan bir çalışmada hematüri etiyolojisi araştırılan 300 hastada AS sıklı̆̆ $\% 1.3$ olarak saptanmıştır. $^{5}$ Beş yüz otuz hematüri tanısıyla izlenen hastanın değerlendirildiği başka bir çalışmada ise hastaların \%1.59'unda AS saptanmıștır.6 Alport sendromu, glomerül bazal membranın (GBM) tip IV kollajen protein ailesindeki $(\alpha 3 / \alpha 4 / \alpha 5)$ mutasyonlar sonucu ortaya çlkar. Genetik olarak heterojen özellik taşır; X'e bağlı resesif, otozomal resesif veya otozomal dominant kalıtım gösterebilir. ${ }^{2}$

Alport sendromu tanısı, tanı kriteri olarak belirlenmiş dört kriterden en az üçünün bulunması ile konulur. Bu kriterler; ailede hematüri ve/veya kronik böbrek yetmezliği öyküsünün bulunması; böbrek biyopsisinde elektron mikroskobik karakteristik bulguların varlığı; yüksek frekansta ilerleyici sensorinöral işitme kaybı; karakteristik göz bulgularının bulunmasıdır. ${ }^{7}$

$\mathrm{Bu}$ çalıșmada, merkezimizde Çocuk Nefroloji Polikliniği'nde takip edilen Alport sendromlu çocuk vakaların demografik, klinik, laboratuvar, histopatolojik ve elektron mikroskobik bulgularının değerlendirilmesi amaçlanmıştır.

\section{Yöntem}

Tanımlayıcl tipte planlanan bu çalışmaya, merkezimizde Çocuk Nefroloji Polikliniği tarafından Haziran 2004 ile Ocak 2018 tarihleri arasinda takip edilen 14 Alport sendromlu hastanın tamamı dahil edildi. Merkezimizde Klinik Araştırmalar Etik Kurulu'ndan çalışma için onay alındı. Hastaların yaşı, cinsiyeti, başvuru şikâyetleri, takip süresi, fizik muayene bulguları, anne-baba akrabalık öyküsü, aile öyküsü, laboratuvar bulguları (kan üre, kreatinin ve albümin değerleri ile idrarda protein ve kan varlığı), göz ve işitme 
muayenesi, renal biyopsi raporları geriye dönük olarak incelendi.

İstatistiksel hesaplamalar 'STATA MP/11 sürümü kullanılarak yapıldı. Çalışma verileri değerlendirilirken yüzde, ortalama gibi tanımlayıcı istatistikler kullanıldı.

\section{Bulgular}

Yedisi kız ve yedisi erkek olmak üzere toplam 14 hasta değerlendirildi. Hastaların yaşları 15 ay-17 yıl arasındaydı (ortalama $10.7 \pm 3.8$ yil). On bir hasta hematüri, bir hasta vücutta şişlik, iki hasta ise şikâyeti olmaksızın baba ve amcasında Alport sendromu olması nedeniyle araştırılmak üzere başvurdu. Anne-baba arasında akrabalık beș hastada mevcutken, 11 (\%78.5) hastanın ailesinde Alport sendromu öyküsü mevcuttu. İlk bașvurudaki laboratuvar incelemelerinde; altı hastada (\%42.85) makroskobik, yedi hastada (\%50) mikroskopik hematüri mevcutken, bir hastada (\%7.15) hematüri saptanmadı (Tablo 1). Dokuz hastada (\%64.2) hematüri ve proteinüri mevcuttu. Bir hasta nefrotik sendrom (\%7.1), iki hasta (\%14.2) son dönem böbrek yetmezliği (SDBY) tablosunda başvurmuştu. Yedi hastanın (\%50) odiyometrisinde sensorinöral işitme kaybı, bir hastanın (\%7.1) göz muayenesinde bilateral anterior lentikonus saptandı. Hastaların dokuzuna merkezimizde, birine dış merkezde olmak üzere $10 \quad$ (\%71.42) hastamıza böbrek biyopsisi yapıldı. Işık mikroskobik (IM) incelemede; sekiz vakada (\%80) mezangioproliferatif glomerülonefrit, bir vakada (\%10) total glomerüloskleroz ve bir vakada (\%10) glomerul bazal membranında (GBM) düzensiz kalınlaşmalar saptandı. İmmünfloresan (IF) incelemede; bir hastada (\%10) IgG ve $\mathrm{C}_{3}$ ile tübüllerde $1(+)$ boyanma, bir hastada (\%10) IgM ile GBM'de lineer, $\operatorname{IgG}$ ve $\mathrm{C}_{3}$ ile mezangiumda fokal granüler boyanma izlenirken sekiz hastamızda (\%80) immün depolanma izlenmedi. Elektron mikroskobik (EM) incelemede; bütün vakalarda GBM'de incelmeler, kalınlaşmalar ve sepet görünümü ile karakterize düzensizlikler izlendi (Resim 1). İzlemde SDBY olup Sürekli Ayaktan Periton Diyalizine alınan iki erkek hastamız (\%14.2), 20 ve 40 aylık takip süresi sonrasında, peritonit ve sepsis ile kaybedildi. Takip süresi 3-108 ay (ortalama 61.5 ay) arasında değișen 12 hastanın tamamının son muayenelerinde mikroskobik hematüri saptandl. Nefrotik sendrom kliniğinde başvuran hastanın takiplerinde hematüri ortaya çıktı. Henüz hiçbir hastamızda kronik böbrek yetmezliği gelişmedi. İzole hematüri ile izlenen dört hastamızın takiplerinde proteinüri de gelişti.

\section{Tartışma}

Çalıșmamızda AS tanısıyla izlenen hastaların demografik, klinik, laboratuvar ve renal histopatolojik özelliklerinin belirlenmesi amaçlanmıştır. Alport sendromu tanisiyla izlenen hastalarla yapılan bir çalışmada ${ }^{8}, 47$ hastanın ortalama tanı yaşı 9 yıl (15 ay-13 yıl) ve erkek/kız oranı 2.1/1 olarak bildirilmiștir. Bizim çalışmamızda ortalama tanı yaşı 10.7 yll (15 ay-17 yıl) olup bu çalışmayla uyumludur. Hastalık tanısı gecikebilmektedir; ancak ailede AS öyküsü olduğunda, çalışmamızda olduğu gibi küçük yaşlarda da tanı konulabilmektedir. Daha önce belirtilen çalışmada 47 hastanın 39'unda (\%82.9) pozitif aile öyküsü bildirilirken, bizim çalışmamızda 14 hastanın 11'inde (\%78.6) pozitif aile öyküsü vardı. Hematüri yakınmasıyla başvuran hastaların aile öyküsünün sorgulanması AS tanısının konulmasında yol gösterici olmaktadır.

Hastalarımızın çoğu \%78.6 (11 hasta) hematüri șikayeti ile bașvurmuștu. Hematüriyle birlikte proteinüri hastaların \%64.2'sinde (9 hasta) saptand. Alport sendromu tanisiyla izlenen hastalarla yapılan diğer bir çalışmada ${ }^{9}, 25$ hastanın tamaminda hematüri ve proteinüri saptanmıș ve bunların sekizinde hematürinin üst solunum yolu enfeksiyonu ile tetiklendiği rapor edilmiștir. Çalışmamızda da dokuz hastada enfeksiyon ile tetiklenen hematüri saptandı. Daha önceden şikayeti olmayan ve enfeksiyonla beraber hematüri saptanan hastalarda ayıricı tanida Alport sendromu düşünülmelidir. 
Tablo 1. Alport Sendromu tanısıyla izlenen hastaların bulguları

\begin{tabular}{lc}
\hline & Hasta sayısı (n=14) \\
\hline Başvuru şikayetleri & 11 \\
Hematüri & 1 \\
Vücutta şişlik & 2 \\
Ailede AS öyküsü & 5 \\
Anne baba akrabalığı & 11 \\
Ailede AS öyküsü & 7 \\
Sensorinöral işitme kaybı & 1 \\
Anterior lentikonus & \\
Laboratuar bulguları-klinik & 4 \\
$\quad$ İole hematüri & $9(2$ SDBY) \\
$\quad$ Hematüri+proteinüri & 1 \\
$\quad$ Nefrotik sendrom & 10 \\
Ișık mikroskobik bulgular & 8 \\
Mezangioproliferatif glomerülonefrit & 1 \\
Glomeruloskleroz & 1 \\
GBM'de düzensiz kalınlaşma & 10 \\
Elektron mikroskobik bulgular & 10 \\
GBM'de incelme, kalınlașma, sepet görünümü &
\end{tabular}

GBM: Glomerul bazal membranı,

SDBY: Son dönem böbrek yetmezliği

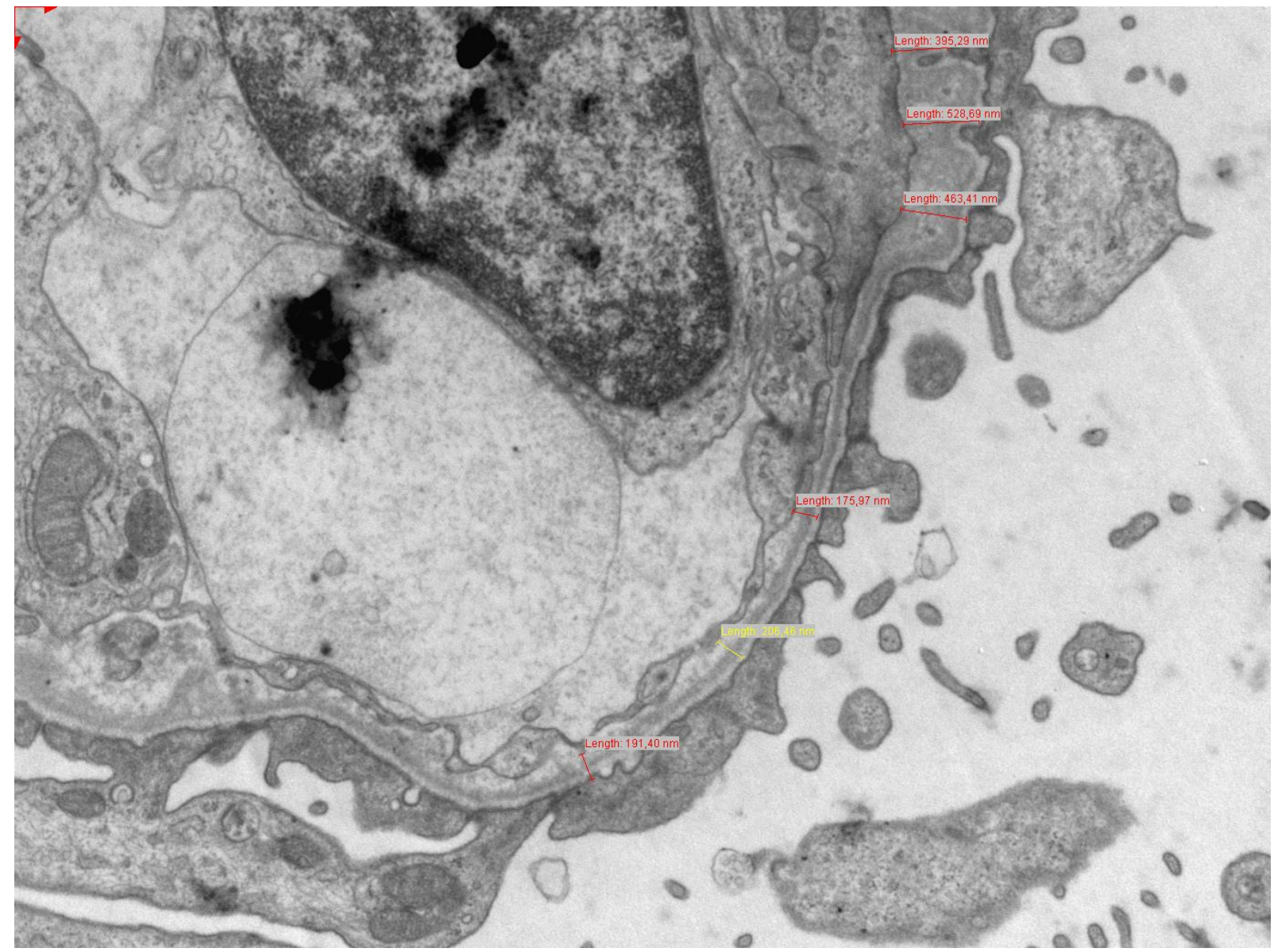

Resim 1. Glomerüler bazal membranda yer yer belirgin incelmeler ve yer yer kalınlaşmalar (11 yaş, erkek) X75000 
Alport sendromunun tipik göz bulgusu retinopati olup erkek hastalarm \%85'inde görülür. Anterior lentikonus olguların yaklaşık \%25'inde, posterior polimorfoz korneal distrofi ise nadiren görülür. Retinopati ve anterior lentikonus çocukluk çağında genellikle görülmez. Retinopati böbrek yetmezliğinin gelişmesiyle beraber görülürken, anterior lentikonus daha sonra gözlenir.10 Çalışmamızda sadece bir hastada anterior lentikonus görülmesi ve bu hastada SDBY'nin eşlik etmesi literatürle uyumludur.

Alport sendromunda işitmeyle ilgili anormallikler genellikle geç çocukluk döneminde ortaya çıkar. Odiyometri ile sıklıkla yüksek frekansta işitme kaybı $(2000-8000 \mathrm{~Hz})$ saptanır. Yenidoğan döneminde işitme testleri normal bulunur. ${ }^{11}$ Çalışmamızda 14 hastanın 7'sinin (\%50) odiyometrisinde sensorinöral işitme kaybı saptanırken; diğer bir çalışmada ${ }^{9} 25$ hastanın ikisinde (\%8) işitme kaybı saptanmıştır. Çalışmamızda işitme kaybı oranının daha fazla olması, hastalara tanı konulan yaş ortalamasının daha yüksek olması ile açıklanabilir.

Alport sendromlu hastaların böbrek biyopsi örneklerinin EM incelenmesinde; küçük çocuklarda GBM'de diffüz incelme görülürken, daha büyük çocuklarda GBM'de diffüz kalınlaşma ve lamina densada sepet benzeri görünümü oluşturan GBM ayrışması gözlenir. ${ }^{12}$ Alport sendromlu çocukların böbrek biyopsilerinin incelendiği bir çalışmada8; IM incelemede 47 hastanın 33'ünde (\%70.2) mezangial proliferatif glomerulonefrit, 13'ünde (\%27.6) fokal segmental glomeruloskleroz ve birinde (\%2.1) membranoproliferatif glomerulonefrit saptanmış. İmmünfloresan incelemede 19 hastada (\%40.4) IgM, dokuz hastada (\%19.1) IgA, dokuz hastada (\%19.1) IgG birikimi saptanırken, 10 hastada (\%21.4) birikim gözlenmemiș. Elektron mikroskobik incelemede tipik GBM değişiklikleri 39 hastada (\%82.9) gözlenmiş. Çalışmamızda renal biyopsi yapılan 10 hastamızın IM incelemesinde, altısında (\%60) literatürle uyumlu olarak mezangial proliferatif glomerulonefrit saptanırken; IF incelemede diğer çalışmalarda baskın olan IgM birikimi sadece bir hastada saptand. Elektron mikroskobik incelemede görülen tipik değişiklikler tüm hastalarımızda mevcuttu. $\mathrm{Bu}$ bulgular, AS düşünülen hastalarda tanıyı kesinleştirmede böbrek biyopsisinin EM incelemesinin önemini göstermektedir.

Alport sendromu tanısı, COL4A3, COL4A4 veya COL4A5 genlerinde patojenik mutasyonların gösterilmesiyle doğrulanır. Genetik test sonuçları, genetik danışma ve hastalığın seyri açısından önemlidir. Genetik testlerin yapılamamış olması çalışmamızın kısıtlılı̆̆ıdır.

Sonuç olarak AS, hematüri ve/veya proteinüriden SDBY'ye kadar geniş bir yelpazede prezente olabilmektedir. Ailede AS öyküsü, işitme kaybı ve göz bulguları tanıyı koymada yol gösterici unsurlardır. Böbrek biyopsisinin EM incelenmesinde, GBM'de tipik değişikliklerin görülmesi tanıyı kesinleştirir.

\section{Kaynaklar}

1.Valentine Gillion, Michel Jadoul, Selda Aydin, Nathalie Godefroid. ANCA vasculitis in a patient with Alport syndrome: a difficult diagnosis but a treatable disease. $B M C$ Nephrology 2017;18:105.

2. Pavlína Plevová, Josef Gut, Jan Janda. Familial hematuria: A review. Medicina 2017;53(1):1-10.

3. Taylor J, Flinter F. Familial haematuria: when to consider genetic testing. Arch Dis Child 2014;99(9):857-861.

4. Kashtan CE. Alport syndrome. An inherited disorder of renal, ocular, and cochlear basement membranes. Medicine (Baltimore) 1999;78:338.

5. Sarı F.N, Bülbül M, Demircan G, Erdoğan Ö, Sarı S, Memiş L, Öner A. Çocukluk çağında hematürinin etiyolojik nedenleri. Türk Ped Arş 2010;45:246-251.

6. Bak M, Uzun H, Serdaroğlu E, Tüzün F, Can D, Gülle S. Çocukluk Yaş Grubunda Hematüri Etiyolojisi. İzmir Tepecik Hast Derg 2005;15(1):23-29. 
7. Frank T.L. Van Der Loop, Laurence Heldet Erıka D.J. Tımmer at al. Autosomal Dominant Alport Syndrome Caused by a Col4a3 Splice Site Mutation. Kidney International. 2000; 58:1870-1875.

8. He X, Liu GL, Xia ZK, Ren XG, Gao YF, Fan $\mathrm{ZM}$ et al. Clinical and pathological sudy of 47 cases with Alport syndrome. Honghua Er Ke Za Zhi. 2008; 46(12):914-918.

9. Sun L, Kuang X, Hao S, Wang P, Niu X, Zhu $G$ et al. Features of clinical phenotype and genotype in Alport syndrome: A monocentric study. Zhonghua Er Ke Za Zhi. 2015; 53(2):114-118.

10. Colville DJ, Savige J. Alport syndrome. A review of the ocular manifestations. Ophthalmic Genet. 1997; 18(4):161-173.

11. Jais JP, Knebelmann B, Giatras I, et al. Xlinked Alport syndrome: Natural history in 195 families and genotype-phenotype correlations in males. J Am Soc Nephrol. 2000; 11:649-657.

12. Kashtan CE, Kleppel MM, Gubler MC. Immunohistologic findings in Alport syndrome. Contrib Nephrol. 1996; 117:142153. 